Article

\title{
Politicization and Regional Integration in Latin America: Implications for EU-MERCOSUR Negotiations?
}

\author{
Andrea C. Bianculli \\ Institut Barcelona d’Estudis Internacionals, 08005 Barcelona, Spain; E-Mail: abianculli@ibei.org
}

Submitted: 31 October 2019 | Accepted: 25 January 2020 | Published: 31 March 2020

\begin{abstract}
Regional integration in Latin America has experienced different periods of politicization. The most recent goes back to the 2000s and is related to the domestic political changes resulting from the so-called 'left turn' which sought alternative economic and development policies to neoliberalism as the state regained centrality. These transformations led to a broad process of politicization of regionalism which changed the terms of the debate surrounding whether regional integration and free trade are the only way for these countries to integrate regionally and internationally. Analyses have thus underscored the postliberal character of this phase of regionalism as reflected in the greater weight of social and political agendas at the expense of economic and trade issues. The Common Market of the South (MERCOSUR) was no exception to this trend. However, in 2010 the bloc rather surprisingly agreed to relaunch negotiations with the European Union (EU). Why did MERCOSUR decide to resume these negotiations-stalled since 2004-in a context of high politicization of regional integration? This article argues that internal politicization did not lead to a paralysis of the international agenda. Moreover, internal politicization, coupled with external pressures and the demand for group-to-group negotiations by the EU, drove and supported the conduct of international negotiations. In so doing, this article also contests the idea that after the 2000s, MERCOSUR moved inexorably towards a postliberal model, thus rejecting any trade component. Findings suggest that these accounts may have overemphasized change and underestimated continuities in regional integration dynamics as the case of the external agenda shows.
\end{abstract}

\section{Keywords}

civil society; European Union; external agenda; Latin America; MERCOSUR; polarization; politicization; regional cooperation; trade negotiations

Issue

This article is part of the issue "Politicization of EU Trade Policy across Time and Space" edited by Dirk De Bièvre (University of Antwerp, Belgium), Oriol Costa (Universitat Autònoma de Barcelona, Spain/IBEI, Spain), Leif Johan Eliasson (East Stroudsburg University, USA) and Patricia Garcia-Duran (University of Barcelona, Spain).

(C) 2020 by the author; licensee Cogitatio (Lisbon, Portugal). This article is licensed under a Creative Commons Attribution 4.0 International License (CC BY).

\section{Introduction}

International and regional governance are depicted as increasingly politicized. From a regional perspective, the case of the European Union (EU) arguably dominates this research agenda. In the case of the Common Market of the South (MERCOSUR), as is the case with regional integration projects in Latin America, where expectations are always high but resources scarce, politicization seems to be the order of the day. Yet, academic interest has been minimal until recently. Politicization has been discussed in relation to trade negotiations, especially in the context of the multitier strategy of trade liberalization deployed in the region in the late 1990s and early 2000s (Bianculli, 2017; von Bülow, 2010). More recently, analyses have investigated cycles of politicization and depoliticization of regional processes (Dabène, 2012). Focus has also been on how politicization affects democracy and legitimacy (Ribeiro Hoffmann, 2015) and parliaments (Mallmann \& Dri, 2011). Again, and in contrast to the proliferation of debates on EU politicization and trade negotiations (Garcia-Duran, Eliasson, \& Costa, 
2020; Meunier \& Czesana, 2019; Poletti \& De Bièvre, 2020; Young, 2019) and external relations more broadly (Costa, 2019), these topics have hardly been discussed in the case of MERCOSUR.

This article aims to contribute to the literature by focusing on the external dimension of MERCOSUR. More specifically, the article explores why MERCOSUR decided to relaunch its interregional negotiations with the EU in a context of high politicization of regional cooperation. While politicization remains a rather ambiguous concept (de Wilde, 2011), this thematic issue builds on the notion of politicization as an increase in polarization of opinions, interests, or values and the extent to which they are publicly advanced towards the process of policy formulation' (de Wilde, 2011, p. 560). Operationally, there is a consensus in the literature that this definition subsumes three observable sub-processes: salience, actor expansion, and polarization. Politicization hence implies rising awareness of an issue, mobilization by a wider array of actors, and increasing polarization of the stances taken by such actors (Hutter, Grande, \& Kriesi, 2016). Building on these insights, but also on those provided by the regionalism literature, in this article I will argue that the degree of politicization is influenced by two elements. First, the degree of consensus between member states on the regional model of development and integration; and secondly, the degree of satisfaction and support of business and civil society to the regional model of development and integration. In operational terms, these translate into intergovernmental conflict and discrepancies over institutional and policy developments at the regional level, such as economic asymmetries and distributive issues, enlargement and association processes, as well as into activism and demands by business and civil society organizations, including economic, participatory, and social issues, correspondingly. Empirically, I focus on a paradigmatic case of interregionalism: the EU and MERCOSUR negotiations for an association agreement. After 20 years of on-off negotiations, the EU and MERCOSUR recently reached a political agreement on a trade deal in June 2019, making the present moment an appropriate time to evaluate whether and how politicization affected the relaunch of negotiations in 2010, which in time led to this agreement.

Regional integration in Latin America has experienced different periods of politicization. Starting in the 2000s, the region underwent domestic political changes resulting from the so-called 'left turn' that sought alternative economic and development policies to neoliberalism as the state regained centrality. These transformations led to a broad process of politicization of regionalism that changed the terms of the debate surrounding whether regional integration as free trade is the only way for these countries to integrate regionally and internationally. MERCOSUR was no exception to this trend. Already in 2003, the debate over the balance between trade and social and political objectives resulted in the relaunch of MERCOSUR, which was to lend greater weight to political and social agendas, including the creation of a regional parliament and the establishment of the first distributive policy. Three years later, divergences over the accession of Venezuela quickly led to the politicization of regional cooperation once again.

Given the above gap in the literature and the renewed interest in trade negotiations and politicization, this article investigates a rather puzzling question: Why did MERCOSUR decide to resume negotiations with the EU-stalled since 2004-in a context of high internal politicization? In so doing, it aims to contribute to a greater understanding of the implications of the tensions between internal and external agendas in regional projects. The article will thus argue that in 2010 MERCOSUR faced several challenges, including discrepancies as to the regional model of development and tensions between member states over the profound asymmetries which gave the most powerful partners an unimpeded capacity for unilateralism, together with increasing salience and criticism from both business and civil society actors. Yet, this still did not discourage the relaunch of negotiations with the EU nor did it prevent further negotiations. While politicization and differences persisted internally, the negotiation with the EU served as a 'glue' bridging internal differences between member states and thus allowing the bloc to act jointly on the external front. Finally, this finding suggests that postliberal accounts underscoring the increasing preponderance of the political and social dimensions of MERCOSUR may have overlooked differences across policy areas, overemphasized change, and underestimated continuities in regional integration dynamics as the external agenda shows.

Methodologically, this is a case study research, seeking to provide an in-depth review of the process of the relaunch of negotiations between MERCOSUR and the EU in 2010. Case studies are appropriate when 'why' questions are posed as these require 'the tracing of operational processes over time' (Yin, 2018, p. 10). In all, this process can be better studied qualitatively by focusing on the internal dynamics between MERCOSUR member states and the increasing polarization within the bloc to then assess why negotiations with the EU were still relaunched. The final purpose is not to generalize the empirical findings of this case but rather to understand the ways in which internal politicization relates to the external dimension of regional blocs in all its complexity, context, and richness; all of which is relevant given the lack of similar studies. The empirical narrative is based on the qualitative method of data collection and analysis, including a combination of documentary sources, i.e., secondary literature, official documents, reports, and newspapers accounts.

The article proceeds as follows: The next section discusses the literature on regional cooperation and politicization in Latin America and introduces the argument. The third section presents an analytical narrative. In 2010, MERCOSUR was still undergoing high internal 
politicization, which included discrepancies among member states over asymmetries and enlargement as well as increasing criticism from various economic and social actors. Yet, and rather counterintuitively, MERCOSUR resumed negotiations with the EU showing that internal politicization did not correlate with international paralysis. On the contrary, internal politicization, coupled with external pressures and the demands for group-to-group negotiations from the EU, drove and supported the conduct of international negotiations. The final section concludes by discussing the main insights and the broader theoretical and empirical implications of this work.

\section{Analysing Regional Integration and Politicization in Latin America}

The politicization of regional integration and cooperation has been the focus of classical scholars who considered the politicization of integration issues as one of the possible causes for the failure of regionalism and regional cooperation (Nye, 1965). Politicization has also been defined as leading to more integration: taken as the process through which actors agree to deal with issues initially considered "technical" or "non-controversial", politicization leads actors 'to upgrade common interests, and in the process, delegate more authority to the centre' (Haas \& Schmitter, 1964, p. 707). However, this does not hold for regionalism and politicization in Latin America. In fact, Dabène has recently contested these assumptions based on a different definition of politicization, which focuses on 'the actors' will to achieve a collective political goal through economic integration' (2012, p. 41). Moreover, whereas high levels of politicization correlate with the intention to recreate and promote further regional cooperation, in the case of Latin America, politicization does not necessarily lead to authority transfer or the ceding of national autonomy; regional organizations remain strictly intergovernmental. Yet, changes may be introduced to upgrade common interests, including democratic consolidation or crisis resolution, and the participation of nonstate actors. Based on these elements, Dabène (2012) goes on to identify cycles of politicization, depoliticization, and repolicization to show that the degree of politicization is positively related to the dynamism of regional processes. Doctor points in this same direction, when arguing that politicization in MERCOSUR has not resulted in increasing sovereignty cession. However, to the extent that starting in the 2000s, 'any shifts were likely to be informed by societal and market actors' changing assessments of the possible benefits of the regionalisation process,' then bottom-up societal-led initiatives could promote deeper integration (Doctor, 2013, p. 537). Finally, when examining the impact of politicization on legitimacy, Ribeiro Hoffmann (2015) claims that whereas MERCOSUR has experienced different phases and peaks of politicization, these have not triggered comprehensive discussions of the bloc's legitimacy. MERCOSUR has also been depicted as having reached a peak of politiciza- tion through the creation of the MERCOSUR Parliament (PARLASUR; Mallmann \& Dri, 2011).

When looking into the conditions under which politicization is more likely to occur in regional projects in Latin America, studies have underscored three driving forces: the level of consensus among member states; the pressures and challenges coming from the activities of opposition parties; as well as from business and civil society organizations (Ribeiro Hoffmann, 2015). In a rather similar vein, a change of government in member states and the level of discontent within the business sector during periods of economic policy change are also factors that may contribute to politicization (Hirst, 1996). Whereas studies dealing with regional cooperation and politicization in Latin America have remained scarce until recently, few attempts have developed comprehensive theoretical or empirical accounts of politicization in regional cooperation and its implications for external trade negotiations.

Trade is a contentious issue and has thus featured in national, regional, and international politics throughout the history of the modern international system. Yet, starting in the 1980s, and more strongly with the advent of the so-called new trade agenda, the shaping of trade policies has raised the stakes and elicited responses from a wider set of societal actors. The mass protests in Seattle (1999) and Cancun (2003) against the World Trade Organization embody this increasing politicization of trade. Yet, these global mobilizations were preceded by the launch and strong agitation and mobilization of the Hemispheric Social Alliance during the Summit of the Americas in Santiago in 1998. Labour and social movements came together under this transnational coalition to expose the perils of increased liberalization and to increase awareness of the need to address these external challenges as portrayed by the Free Trade Area of the Americas (FTAA). Certainly, the broad and deep scope of North-South trade negotiations, i.e., bridging developing and industrialized countries, elicited a variety of collective strategies and trade politics. However, confrontational strategies were more strongly used after the launch of the FTAA and were practically negligible in the context of trade negotiations with the EU. Despite promoting similar economic and regulatory trade agendas, long years of intensive collaboration and cooperation preceded negotiations with the $\mathrm{EU}$ in line with the idea of this bloc as a civilian and normative power (Bianculli, 2017). As a result of these transformations, the trade arena became multifaceted and politically and socially challenging in Latin America, where countries had immersed themselves in a rapid process of trade liberalization and deregulation after 50 years of sealed markets. Concomitantly, the political dynamics of international trade in the region, which had remained rather neglected in studies of international political economy until then, gained centrality and scholars intended to move beyond the dominance of models inspired by and designed to account for trade politics in the United States and to a lesser extent in the EU and Canada (see among 
others, Bianculli, 2017; Lengyel \& Ventura-Dias, 2004; Tussie, 2003).

Similarly, the literature on the external dimension of regional integration has remained minimal even if one of the characteristics of the new or open regionalism of the 1990s was the development of an external agenda. Contrary to the old regionalism, this new wave of regional cooperation was mainly conceived as a trade centred enterprise and as a mechanism to strengthen the bargaining power of member countries and thus assure their successful insertion into the global economy (Bianculli, 2016). The centrality of the external dimension would then lead to a common external policy, 'at least as a reaction to third-country demands' (Torrent, 2003, p. 126).

Studies looking into the external dimension of MERCOSUR have argued that apart from establishing a link between the internal and external agendas, external negotiations have progressively formed the 'glue' binding member countries together, providing incentives for the resolution of their competing interests (Phillips, 2003). This especially holds for EU-MERCOSUR group-togroup negotiations; if signed, the agreement could support further consolidation of the bloc (Rios \& Doctor, 2004; Santander, 2005). Yet, a second vision has contended that rather than functioning as a unifying element, the external agenda evidences the limits of the internal agenda of the bloc, and thus works merely as a 'flight forward,' an evasive action which does not really strengthen MERCOSUR (Carranza, 2006, p. 809). Finally, Doctor (2015) presents and discusses a third view, mostly evident among policymakers though weakly developed in the literature (Malamud, 2005; Oelsner, 2013), which claims that the external agenda has, in fact, added more topics and initiatives to the internal agenda, thus straining the regional process of integration.

This article argues that still in 2010 the external agenda worked again as the much-needed glue or unifying element that MERCOSUR required to go on despite the politicization of the bloc and the increasing challenges the regional integration process faced. Additionally, and contrary to the idea that cycles of politicization may trigger reform and further institutionalization, this does not seem to hold for the external agenda. This may be explained by the intergovernmental character of decision making in MERCOSUR, which is exacerbated in the case of the external agenda where the issues invoked may involve significant national sensitivities and where presidents, especially those holding the rotating (pro tempore) presidency, become key protagonists and gain great international visibility (Tallberg, 2010).

\section{MERCOSUR, Politicization, and External Relations}

MERCOSUR was part of the ambitious strategy of trade liberalization through regional, interregional, and multilateral agreements pursued by countries in the Southern Cone starting in the 1990s.
Set up in 1991, MERCOSUR marked the transition from state-led policies and a cautious approach to regional integration, to market-oriented agendas and a more open and wide-ranging strategy of regional trade liberalization. MERCOSUR's main objective, as established by the four founding members-Argentina, Brazil, Paraguay, and Uruguay-was hence to create a common market while also pursuing 'economic development with social justice' in the region (MERCOSUR, 1991). Twenty years after its creation, MERCOSUR was ranked as one of the regional projects 'that have reached the greatest level of formal accomplishment after the EU' (Malamud \& Schmitter, 2011, p. 135). However, while even today much remains to be done, especially considering that the development of the common market and the customs union is still incomplete, MERCOSUR has also pursued regional cooperation in a wide array of policy areas, including human rights, social policies, education and culture, health, gender, migration, and tourism, among others, though with varying levels of accomplishment.

Over the years since its inception, MERCOSUR has undergone cycles of politicization and depoliticization (Dabène, 2012) and has also gone through peaks of politicization (Ribeiro Hoffmann, 2015). As argued in the case of the EU, the politicization of MERCOSUR can be characterized by 'a patchwork of politicizing moments' (Hutter et al., 2016, p. 283) rather than by a uniform and increasing trend pattern. Politicization intensified or reached a peak during institutional and policy-related events at the regional and the national levels.

The first years of the bloc did not give rise to any major controversies. Moreover, during the first half of the 1990s, MERCOSUR made notable achievements. First, this period was defined by a strong alignment between the domestic policies and the regional objectives of the two largest member states: Argentina and Brazil. Secondly, economic gains were considerable: The share of intra-MERCOSUR exports rose from 9 to 25\% from 1990-1998 while annual foreign direct investment inflows reached over US\$ 50 billion by 1999 (Inter-American Development Bank, 1999). Finally, in 1994, the Protocol of Ouro Preto established the institutional structure of MERCOSUR, which remained strictly intergovernmental while decision-making processes were based on consensus. This Protocol also introduced a relevant institutional novelty by setting up two bodies intended to assure citizen representation: The Joint Parliamentary Commission and the Economic and Social Consultative Forum, which was to work as the 'representative body of the economic and social sectors,' (MERCOSUR, 1994, Art. 28) i.e., business and labour. Even if these mechanisms were limited, MERCOSUR remained mostly out of the spotlight of wider societal interests. Labour and civil society organizations' agenda focused on domestic issues, i.e., labour reform and the impact on salaries, employment, and working conditions, as well as on democracy, respectively. By the mid-1990s, these actors started debating the labour, so- 
cial, and environmental problems arising from integration; yet, regional networks, including the Southern Cone Coordinator of Central Trade Unions, viewed MERCOSUR as a mechanism to strengthen social and environmental standards and regulations (Botto, 2004). Similarly, as intra-bloc trade and investment grew, business devised new regional forms of interest representation (Schelhase, 2010).

The increasing awareness of societal actors coincided with a crowded internal agenda. The 1996 democratic crisis in Paraguay, a coup against the elected president, triggered a process of politicization. The remaining member states, under the leadership of Argentina and Brazil, provided an immediate diplomatic response that turned out to be crucial in resolving the crisis. Two years later, the Protocol of Ushuaia-an analogous democratic clause, the first in the region-formalized MERCOSUR's commitment to democracy.

This internal politicization did not affect the external trade agenda. Free trade agreements with a focus on trade in goods were signed on a bilateral basis with Bolivia and Chile as early as 1996. In fact, since 1994, MERCOSUR maintained an active and ambitious external agenda, and the bloc succeeded in projecting itself internationally. MERCOSUR was conceived as an instrument to increase the presence and bargaining power of member countries in the international arena (MERCOSUR, 1991). More specifically, the founding treaty established that the creation of the common market entailed some common actions, including the adoption of a common trade policy in relation to third states or grouping of states, and the coordination of positions in regional and international commercial economic forums' (MERCOSUR, 1991, Art. 1). Moreover, states then committed 'to coordinate their positions in the external trade negotiations undertaken during the transition period' (MERCOSUR, 1991, Art. 8). These commitments led to the creation of various mechanisms, including the establishment of common criteria for the negotiation of regional and international negotiations and the adoption of a most-favoured-nation clause (Zelicovich, 2015), which required that any advantage or privilege, i.e., reduced tariffs, granted to another nation had to be accorded to all member countries. In fact, the joint reduction of most-favoured-nation tariffs and the reduction of intra-area preferential tariffs accounts for the enormous initial success of MERCOSUR (Estevadeordal, Goto, \& Saez, 2000). From a decision-making perspective, these innovations would imply celebrating meetings between MERCOSUR partners or member states instructing their delegations to strengthen the coordination of positions and joint actions on these matters.

In 1994, the Protocol of Ouro Preto further enhanced these commitments by establishing MERCOSUR's international legal personality, which falls on the Common Market Council (CMC)-the highest decision-making power; thus, allowing the bloc to represent the four member states in regional and international negotia- tions. Different decisions and resolutions issued by internal decision-making bodies would then set the guidelines for the coordination of positions and joint action of member states, including the creation of an Ad Hoc Group of External Relations within the Common Market Group (CMG), the MERCOSUR executive body (MERCOSUR, 1995b, № 34/95). This was to deepen the common external agenda, especially in terms of MERCOSUR relations with third countries, groupings of countries, and international organizations, thus reinforcing coordination mechanisms between technical teams in member countries to articulate policies and concrete joint actions. Yet, the external representation of the bloc would rely on the rotating (pro tempore) presidency.

In the mid-1990s and early 2000s, the bloc's external agenda was especially marked by the negotiation of asymmetric or North-South agreements; namely, the United States-led process for the establishment of an FTAA from Alaska to Tierra del Fuego launched in 1998 and which finally collapsed in 2005, and the negotiations with the EU. These negotiations turned out to be particularly challenging for MERCOSUR external dynamics given that they involved not only the reduction or elimination of tariffs and other non-tariff barriers on the trade of goods and services but also deeper issues that had become difficult to negotiate at the World Trade Organization, namely, investment rules, intellectual property rights, and government procurement, among others. Interregional negotiations with the EU were especially relevant in this respect.

The EU-MERCOSUR relationship is based on the Interregional Framework for Agreement (EMFICA) signed in 1995 to promote an Interregional Association Agreement founded on three pillars: trade liberalization, political dialogue, and cooperation. MERCOSUR would then set the mechanisms to coordinate joint actions between member states' experts and technical specialists while delegating the negotiation of the EMFICA to the CMG (MERCOSUR, 1995a, № 5/95). After many years of intense and legally driven relations across the Atlantic, trade negotiations were launched in 1999. Negotiations with the EU would prompt MERCOSUR to speak with a single voice. Building on MERCOSUR guidelines but also on an EU requisite, member countries had to find a common regional position before sitting at the interregional table. Negotiations would thus assume a bloc format, ruling out negotiating on an individual country basis. This requirement had a double effect. From an internal dimension, it triggered a learning by doing process among member countries, as they had to 'learn' to harmonize their national positions. Additionally, given the breadth and depth of the agendas under negotiation, MERCOSUR countries were to discuss regulatory and policy standards and norms that were not part yet of their regional agenda, i.e., government procurement and services. And from an external dimension, this learning process transferred to other negotiations, including those of the FTAA despite the United States' initial resis- 
tance to this bloc format (Botto \& Bianculli, 2011). After 15 rounds, negotiations were abandoned in 2004 due to differences over the trade agenda, which covered not only industrial and agricultural goods but also services, government procurement, intellectual property rights, customs and trade facilitation, as well as technical barriers to trade, mainly in manufactured goods, services, and agriculture; it would take a hiatus of six years for negotiations to be re-launched.

By the mid-2000s, MERCOSUR had already consolidated its negotiation dynamics based on the elaboration of each country's national position according to their interests and priorities (both defensive and offensive), which would then be circulated among the four member states to harmonize and prepare the final MERCOSUR document to be presented at a later time to the negotiating counterpart (Botto \& Bianculli, 2011).

\section{MERCOSUR, Politicization, and yet Negotiations with the EU}

\subsection{MERCOSUR and a New Long Cycle of Politicization}

In 1999, internal politicization was high again, and MERCOSUR faced a 'terminal crisis.' Tensions between Argentina and Brazil peaked after the abrupt devaluation of the Brazilian currency in January 1999. As a result, a series of trade disputes and a fall in intra-group trade put MERCOSUR at risk. In late 2001, another crisis shook the regional process when Argentina suffered an extraordinary economic, political, and social breakdown. What had been proclaimed as the demise of MERCOSUR, in fact, gave the bloc a new lease of life. In all, the 1998-2002 cycle of politicization crisis revealed two different regional responses. Whereas the turmoil highlighted the economic limitations of the bloc, regional developments underscored the relevance of the political dimension of MERCOSUR. Both economic shocks were followed by efforts to relaunch the project: The Buenos Aires Agenda in 2000 and the Buenos Aires Consensus in 2003. Whereas the Buenos Aires Agenda, which included, inter alia, the creation of a more transnational and permanent dispute settlement mechanism (Arnold \& Rittberger, 2013), was scarcely implemented, by mid2003, the convergence between Argentina and Brazil was reinforced by a certain shared socio-political affinity between the two left-oriented presidents: Néstor Kirchner and Lula da Silva. Both leaders campaigned on platforms of scepticism toward the value of economic and trade liberalisation, and of the need for alternative political, economic, and development policies at the domestic level where the state was to play a central role. This resonated at the regional level.

A normative consensus emerged among MERCOSUR member states regarding the need to replace the emphasis on economic and trade liberalization by strengthening cooperation in monetary, financial, and energy issues (Motta Veiga \& Rios, 2007), as well as in the politi- cal, social, and productive (i.e., regional industrialization) dimensions of regionalism. Yet, structural challenges to further integration became evident. First, the significant economic asymmetries among partners, i.e., between Brazil and other members, and in relation to the two smallest members, Uruguay and Paraguay, made it difficult to respond effectively to the bloc's crises and to deepen integration. In 2005, analysts warned of a serious danger of MERCOSUR's collapse ('Mercosur: Peligro de derrumbe,' 2005). Secondly, although initially, it was an elite and state-led project, in time the bloc gradually began to experience a growing projection within society and faced increasing demands from business and civil society. On the one hand, business was strongly demanding deeper economic coordination, measures to counterbalance structural imbalances and asymmetries, and the promotion of productive integration. A strong questioning of MERCOSUR resonated among industrialists in Argentina and Brazil. Civil society, on the other hand, demanded greater participation and transparency in MERCOSUR decision-making processes. In all, free trade negotiations, mainly North-South processes, had triggered a learning process in NGOs and transnational networks, who would now redirect their attention towards MERCOSUR (Botto, 2015). From an internal perspective, this politicization resulted in MERCOSUR being institutionally transformed in several ways. The first redistributive policy was created through the Fund for MERCOSUR Structural Convergence in 2004, followed by the upgrade of the Joint Parliamentary Commission into a regional parliament-PARLASUR-in 2005. With the creation of PARLASUR, the number of actors involved in the regional public debate expanded, leading in principle to more politicization. Other relevant transformations included the creation of the program 'We are MERCOSUR' and the MERCOSUR Social Summits to strengthen the role and participation of civil society, as well as of the Council of Ministers of Social Development in 2005, and the MERCOSUR Social Institute in 2007 to further enhance the formulation of regional social policies. Whereas these various measures helped to contain the increasing polarization of MERCOSUR, this would peak with the accession of Venezuela. Having been an associate member since 2004, Venezuela asked for full membership in 2005 and finally signed the accession protocol with the four founding members in 2006. MERCOSUR thus undertook its first enlargement. Yet, the dynamics of this issue's politicization would remain remarkably similar. Ratification by national congresses in Brazil and Paraguay lingered because of domestic opposition, while business in Argentina and Brazil vocally opposed the accession of Venezuela.

The external dimension received a strong institutional push within the 2000 relaunch of MERCOSUR. The CMC issued a decision on the need to enhance the external relations of MERCOSUR through the development of a common external trade policy and the commitment of member states to negotiate trade agreements jointly 
(MERCOSUR, 2000, № 32/00). Based on this renewed regional approach to external relations, MERCOSUR created a Negotiating Group made up of full-time negotiators on behalf of each member state and under the leadership of a coordinator. The main objective was to define a common negotiation platform, in which bilateral negotiations should be prioritized, starting with those with the EU and the United States (MERCOSUR, 2001, № 08/01). While relevant, these institutional developments did not alter the intergovernmental character of the MERCOSUR decision-making process. Moreover, the rotating (pro tempore) presidency would still be the main responsible for the external agenda of the bloc and international negotiations.

During the early years of the 21st century, MERCOSUR led an active external agenda. The strong normative consensus on the model of development seems to account for the South-South agreements signed with Mexico (2002), Morocco and India (2004), and Peru (2005), and the three Economic Complementation Agreements established with the Andean Community in 2004. Similarly, 2005 stood out as the year when the FTAA collapsed because of its unanimous rejection by MERCOSUR countries together with Bolivia and Venezuela, among other factors. However, the internal reorientation of the agenda away from trade liberalization and open regionalism did not lead to a formal rejection of negotiation and agreements with developed, industrialized countries (Motta Veiga \& Rios, 2019, p. 12).

\subsection{Giving Negotiations with the EU a New Chance}

The suspension of trade negotiations between MERCOSUR and the EU in 2004 did not bring about a break in the interregional relations. These continued through ministerial and technical meetings that ratified the mutual interest in the reopening of negotiations while strengthening political dialogue and technical and financial cooperation in diverse policy sectors, i.e., trade facilitation, sanitary harmonization, and education, for a total amount of 50 million Euros to be executed between 2007 and 2013. In May 2008, during the Fifth Summit between the EU, Latin America, and the Caribbean, the EU and MERCOSUR renewed their commitment to strengthening cooperation in projects of mutual interest, including infrastructure, renewable energy sources, science and technology, and their political and economic relations, i.e., the successful conclusion of the association agreement (Council of the European Union, 2008). This was followed by two informal meetings in 2009 where EU and MERCOSUR negotiators exchanged views on their positions, especially those of mutual interest, to recommend to the member states of both regional organizations the resumption of negotiations in view of the presidential meeting scheduled within the Latin American and the Caribbean-EU Summit for May 2010 under Spain's EU Presidency. Based on these discussions, in the MERCOSUR Summit that took place in December 2009 in Montevideo, the Argentine President, Cristina Fernández, announced that as coming pro tempore president of MERCOSUR, she would promote an agreement between the bloc and the EU, which was one of the most relevant challenges of MERCOSUR, while calling for the collaboration of the Brazilian president to achieve this agreement ('Cristina Kirchner pidió una discusión profunda,' 2009; 'Cristina y Zapatero anunciaron,' 2009).

Finally, in May 2010, both sides renewed 'their commitment to strive for a conclusion of the negotiations without delay' (Council of the European Union, 2010).

These calls, however, were made in a regional context marked by the politicization of MERCOSUR while the model of regional integration was undergoing serious criticism and challenges from within. First, tensions between Argentina and Brazil in the commercial and economic spheres because of trade disputes and the existence of asymmetries within the bloc hampered the deepening of the regional project ('Las asimetrías dentro del bloque,' 2008). Friction was also evident with the smaller partners of the bloc. Uruguay was very vocal in expressing that MERCOSUR was undergoing a critical phase as the bloc lacked political and economic coordination. This turned out to be especially serious at a time when other regional projects were surging and gaining strength as it was the case of the Union of South American Nations (Rebossio, 2011). Secondly, criticisms were abound at that time due to the internal differences and the small number of free trade agreements concluded by MERCOSUR, which by then mainly included those with Southern partners and Israel. Finally, the accession of Venezuela was still subject to strong criticism and opposition. Ratification by the Paraguayan national congress yet lingered in 2010 as the President, Fernando Lugo, withdrew the request from Venezuela to join MERCOSUR from the Congress, as he questioned whether the Venezuelan government was democratic ('Lugo vuelve a frenar,' 2010).

Despite this context, MERCOSUR decided to relaunch the negotiations with the EU. These negotiations offered a window of opportunity for the bloc to appear coherent and unified. In other words, the negotiation again acted as glue within the bloc. This is illustrated by the decision of Argentina and Brazil, the two larger members of the bloc, to overlook the difficulties and tensions between them and to move forward and secure the interregional agreement (Gualdoni \& González, 2010).

Negotiations with the EU were expected to improve the image of MERCOSUR (Rebossio, 2010). In so doing, the bloc was also consistent with one of the main objectives set in 1991: Regional integration should help increase these countries' bargaining power in the international arena. By then, a joint and common foreign policy and the diversification of external relations was expected to contribute to reducing internal imbalances (Gualdoni \& González, 2010). Similarly, while strengthening regional cooperation and integration policies, an agree- 
ment with the EU would give a response to those criticisms that portrayed MERCOSUR as being paralyzed or weakened. Moreover, international agreements should not be taken as a reciprocal limitation of autonomy, but as a means to facilitate access to a particular set of otherwise unattainable international public goods, as put by Eduardo Sigal, former Argentine Sub-Secretary of Economic Integration for Latin America and MERCOSUR (Sigal, 2010).

Secondly, and regarding the conflictual process of accession of Venezuela, business in Argentina and Brazil vocally opposed the accession. The Argentina Industrial Union (UIA), the main industrial chamber, asked the national government to revise the decision to accept Venezuela as full member given that this country's economic policies were in direct contradiction with those of MERCOSUR as shown by the nationalization of MERCOSUR companies, i.e., Techint. Similar criticisms were expressed by other business chambers and associations, including exporters and metallurgic industries. Further measures undertaken by business associations included a meeting with opposition parties in the national Congress and an extraordinary meeting of the MERCOSUR Industrial Council after contacting their counterparts in Brazil and Uruguay. From the Argentine perspective, this ended the honeymoon between the Kirchner administration and the industrialists (Olivera, 2009). Thus, an agreement with the EU would satisfy some of the industrialists' demands not only in Argentina but also in Brazil, bringing both administrations closer to these sectors. Additionally, the EU made clear that Venezuela would not be part of the negotiation process. Certainly, this was not in the interest of Venezuela given the strong anti-capitalist approach to regional integration as illustrated by the creation and leadership of the Bolivarian Alliance of the Americas.

Finally, the relaunch of this negotiation process was made possible by the leadership and image of the presidents, especially those holding the rotating (pro tempore) presidency. Certainly, the interregional negotiation process gave the presidents greater visibility at the international level. In the case of Argentina, the administration was able to use the agreement with the $\mathrm{EU}$ as an international success and thus, improve its image, which had deteriorated due to the increase in protectionist measures adopted by Argentina ('La ilusión de libre comercio,' 2010). This country was not only blocking imports from its regional partners but also from the EU and from all over the world ('La UE exige a Argentina,' 2010). Brazil, under the lead of Lula, was also interested in making up for lost time and to move quickly towards an agreement with the EU before the presidential elections to be held early in 2011. More specifically, he highlighted that he would use his MERCOSUR pro tempore presidency to leave the complex interregional trade agreement threaded before leaving office in December 2010 (Barón, 2010). In this respect, Lula's position differed from the candidate who was then presented as his suc- cessor who had already underscored that Brazil should negotiate free trade agreements on its own, irrespective of MERCOSUR commitments since Brazil was vastly better positioned to further economic negotiations with the EU than its regional partners (Arias, 2010). These declarations were a source of concern for Argentina as well.

In all, in 2010 the external agenda provided the glue that held MERCOSUR together. As the strong consensus on the model of regional development that characterized the initial years of the 21st century started to dilute, differences and asymmetries emerged among member states while facing the criticism of societal actors, mainly business. Negotiations with the EU allowed member states to define and agree on common interests, preferences, and goals. Moreover, signing the interregional agreement with the EU actually improved the internal and external image of the bloc; thus, providing motivation to move forward with the agreement. During this process, presidents played a key role. This is explained by the intergovernmental character of MERCOSUR, but also by the 'power of the chair,' i.e., the rotating (pro tempore) presidency, that gives formal leaders greater room for manoeuvre and are thus more capable to influence negotiations (Tallberg, 2010).

\section{Conclusions}

This article has examined the relationship between the internal politicization of regional cooperation and external relations through the analysis of MERCOSUR and the relaunch of the negotiation process with the EU in 2010. Certainly, MERCOSUR has gone through different cycles of politicisation. Both domestic and regional institutional and policy factors account for these cycles. The politicization of the bloc during the 2000s, mainly expressed through the priority given to the political and social agendas, became diluted in time as tensions between member states due to asymmetries and protectionism, the accession of Venezuela, and the increasing demands from economic and social actors put MERCOSUR to the test once again. This initiated a long period of politicization reaching a peak between 2004 and 2006. Yet, some of the main factors persisted and were evident in May 2010 when the bloc restarted free trade negotiations with the EU.

Internal politicization has not negatively affected MERCOSUR's main approach to its international relations and negotiations but rather reinforced its capacity to act as a negotiating bloc, presenting common proposals and positions in the different negotiations. Furthermore, even in 2000 in the context of what was perceived as the end of the bloc because of the severe crisis and politicization what was underway, MERCOSUR issued a resolution to reassert its commitment to negotiate as a bloc. Limited institutional changes were also introduced. In all cases, including the relaunch of negotiations with the EU in 2010, the external agenda has served as the glue to keep the bloc functioning as one even when facing chal- 
lenges on the internal front. This may be explained by the intergovernmental character of decision making in MERCOSUR, which is exacerbated in the case of the external agenda where the issues invoked may involve significant national sensitivities and where presidents, especially those holding the pro tempore presidency gain great international visibility and leadership.

The international activism of MERCOSUR has remained constant throughout its almost 30 years of history despite its politicization cycles. In the 1990s, the agenda moved from South-South agreements to asymmetric agreements, where the EU assumed a very important place. During the 2000s, South-South agreements were pursued with extra-regional countries, i.e., Egypt (2010), and bloc to bloc agreements as in the case of the Southern Africa Customs Union (2008). In 2010, the EU was again back on the agenda; in fact, it never left. Furthermore, and despite the reorientation of the bloc towards a more developmentalist model, the international agenda did not vary substantially. There was no formal contestation of asymmetric or North-South agreements mostly pursued within the new or open regionalism paradigm.

This last insight speaks to the literature that mainly describes regionalism in Latin America as occurring in waves, and which in so doing, tends to overemphasise change and underestimate continuity. While studies have underscored that since the 2000s, Latin America, and especially South America had moved towards a new phase of regionalism, away from what had been the main tenets of the neoliberal creed of the 1990s, in this case, negotiations with the EU were not openly contested. Furthermore, internal politicization did not affect the external agenda; rather, the external pressures from the group-to-group negotiations, as required by the EU, caused internal politicization to actually drive and support the pursuit and conduct of international negotiations.

Finally, this insight brings the question of whether and how there may be variation in the effects and outcomes of the process of internal politicization across policy areas as recent research on the EU has shown (see among others, Biermann, Guérin, Jagdhuber, Rittberger, \& Weiss, 2019; Börzel \& Risse, 2018; Schimmelfennig, 2018). Whereas this article has found that internal politicization does not translate into international paralysis, but rather can reinforce and support the external agenda of regional blocs, further research could explore whether and how this holds for other policy areas. This is of relevance for both the literature on politicization and comparative regionalism.

\section{Acknowledgments}

I would like to thank the editors of this thematic issue and two anonymous reviewers for their insightful and constructive comments and suggestions.

\section{Conflict of Interests}

The author declares no conflict of interests.

\section{References}

Arias, J. (2010, July 17). Los socialdemócratas en Brasil apuestan por un tratado con la UE que no dependa de Mercosur [Social democrats in Brazil support a treaty with the EU that does not depend on Mercosur]. El País. Retrieved from https://elpais.com/ internacional/2010/07/17/actualidad/1279317601 850215.html

Arnold, C., \& Rittberger, B. (2013). The legalization of dispute resolution in Mercosur. Journal of Politics of Latin America, 5(3), 97-132.

Barón, F. (2010, July 15). Lula impulsa las negociaciones entre Mercosur y la UE [Lula promotes negotiations between Mercosur and the EU]. El País. Retrieved from https://elpais.com/tecnologia/2010/ 07/15/actualidad/1279182478_850215.html

Bianculli, A. C. (2016). Latin America. In T. A. Börzel \& T. Risse (Eds.), The Oxford handbook of comparative regionalism (pp. 154-177). Oxford: Oxford University Press.

Bianculli, A. C. (2017). Negotiating trade liberalization in Argentina and Chile: When policy creates politics. New York, NY: Routledge.

Biermann, F., Guérin, N., Jagdhuber, S., Rittberger, B., \& Weiss, M. (2019). Political (non-)reform in the euro crisis and the refugee crisis: A liberal intergovernmentalist explanation. Journal of European Public Policy, 26(2), 246-266.

Börzel, T. A., \& Risse, T. (2018). From the euro to the Schengen crises: European integration theories, politicization, and identity politics. Journal of European Public Policy, 25(1), 83-108.

Botto, M. (2004). Los nuevos regionalismos y la acción colectiva transnacional [New regionalisms and transnational collective action]. Perfiles Latinoamericanos, 25, 9-41.

Botto, M. (2015). La integración regional en América Latina: Quo vadis? El Mercosur desde una perspectiva sectorial y comparada [Regional integration in Latin America: Quo vadis? Mercosur from a sectoral and comparative perspective]. Buenos Aires: Eudeba.

Botto, M., \& Bianculli, A. C. (2011). Comparative asymmetric trade negotiations in the Southern cone: FTAA and EU-MERCOSUR. In S. Bilal, P. De Lombaerde, \& D. Tussie (Eds.), Asymmetric trade negotiations (pp. 83-120). Aldershot: Ashgate.

Carranza, M. E. (2006). Clinging together: Mercosur's ambitious external agenda, its internal crisis, and the future of regional economic integration in South America. Review of International Political Economy, 13(5), 802-829.

Costa, O. (2019). The politicization of EU external re- 
lations. Journal of European Public Policy, 26(5), 790-802.

Council of the European Union. (2008). MERCOSUREuropean Union Troika Summit: Joint Declaration. Brussels: European Union. Retrieved from https:// www.consilium.europa.eu/uedocs/cms_Data/docs/ pressdata/en/er/100459.pdf

Council of the European Union. (2010). IV EU-Mercosur summit joint communiqué. Brussels: Council of the European Union. Retrieved from https:// www.consilium.europa.eu/uedocs/cms_data/docs/ pressdata/en/er/114486.pdf

Cristina Kirchner pidió una discusión profunda de las asimetrías para evitar "problemas irresolubles" en la región [Cristina Kirchner called for an in-depth discussion of asymmetries to avoid "unsolvable problems" in the region]. (2009, December 8). La Nación. Retrieved from https://www.lanacion.com.ar/politica/ cristina-kirchner-pidio-una-discusion-profunda-delas-asimetrias-para-evitar-problemas-irresolublesen-la-region-nid1209246

Cristina y Zapatero anunciaron que buscarán un acuerdo entre el Mercosur y la UE [Cristina and Zapatero announced that they will seek an agreement between Mercosur and the EU]. (2009, November 30). La Nación. Retrieved from https://www.lanacion.com. ar/politica/cristina-y-zapatero-anunciaron-quebuscaran-un-acuerdo-entre-el-mercosur-y-la-uenid1206129

Dabène, O. (2012). Consistency and resilience through cycles of politicization. In P. Riggirozzi \& D. Tussie (Eds.), The rise of post-hegemonic regionalism: The case of Latin America (pp. 41-64). Dordrecht: Springer.

de Wilde, P. (2011). No polity for old politics? A framework for analyzing the politicization of European integration. Journal of European Integration, 33(5), 559-575.

Doctor, M. (2013). Prospects for deepening Mercosur integration: Economic asymmetry and institutional deficits. Review of International Political Economy, 20(3), 515-540.

Doctor, M. (2015). Interregionalism's impact on regional integration in developing countries: The case of Mercosur. Journal of European Public Policy, 22(7), 967-984.

Estevadeordal, A., Goto, J., \& Saez, R. (2000). The new regionalism in the Americas: The case of MERCOSUR (Working Paper No. 5). Buenos Aires: Institute for the Integration of Latin America and the Caribbean.

Garcia-Duran, P., Eliasson, L. J., \& Costa, O. (2020). Managed globalization 2.0: The commission's response to trade politicization. Politics and Governance, 8(1), 290-300.

Gualdoni, F., \& González, M. (2010, May 18). La UE y Mercosur buscan cerrar un acuerdo de libre comercio este año [EU and Mercosur seek to conclude a free trade agreement this year]. El País. Retrieved from https://elpais.com/diario/2010/05/18/ internacional/1274133606_850215.html

Haas, E. B., \& Schmitter, P. C. (1964). Economics and differential patterns of political integration: Projections about unity in Latin America. International Organization, 18(4), 705-737.

Hirst, M. (1996). La dimensión política del Mercosur: Actores, politización e ideología [The political dimension of Mercosur: Actors, politicization and ideology]. Estudos Avançados, 10(27), 217-250.

Hutter, S., Grande, E., \& Kriesi, H. (2016). Politicising Europe: Integration and mass politics. Cambridge: Cambridge University Press.

Inter-American Development Bank. (1999). Integration and trade in the Americas: Periodic note. Washington, DC: Inter-American Development Bank.

La ilusión de libre comercio [The illusion of free trade]. (2010, April 18). La Nación. Retrieved from https://www.lanacion.com.ar/economia/la-ilusionde-libre-comercio-nid1255207

La UE exige a Argentina que 'deje de bloquear' importaciones [EU demands Argentina to 'stop blocking' imports]. (2010, June 28). Clarín. Retrieved from https://www.clarin.com/economia/ue-exigeargentina-bloquear-importaciones_0_ BJmDRBIAPXe.html

Las asimetrías dentro del bloque siguen pendientes [Asymmetries within the block are still pending]. (2008, January 8). La Nación. Retrieved from https:// www.lanacion.com.ar/economia/comercio-exterior/ las-asimetrias-dentro-del-bloque-siguen-pendientes -nid976572

Lengyel, M. F., \& Ventura-Dias, V. (2004). Trade policy reforms in Latin America. Multilateral rules and domestic institutions. London: Palgrave Macmillan.

Lugo vuelve a frenar el ingreso de Venezuela al Mercosur [Lugo once again slows down Venezuela's entry into Mercosur]. (2010, December 9). La Nación. Retrieved from https://www.lanacion.com.ar/elmundo/lugo-vuelve-a-frenar-el-ingreso-devenezuela-al-mercosur-nid1332062

Malamud, A. (2005). Presidential diplomacy and the institutional underpinnings of MERCOSUR: An empirical examination. Latin American Research Review, 40(1), 138-164.

Malamud, A., \& Schmitter, P. C. (2011). The experience of European integration and the potential for integration in South America. In A. Warleigh-Lack, N. Robinson, \& B. Rosamond (Eds.), New regionalism and the European Union: Dialogues, comparisons and new research directions (pp. 135-157). London and New York, NY: Routledge.

Mallmann, M. I., \& Dri, C. F. (2011). Institucionalización y politicización de la integración [Institutionalisation and politicisation of integration]. In J. Briceño-Ruiz (Ed.), El Mercosur y las complejidades de la integración regional [Mercosur and the complexities of regional integration] (pp. 203-223). Buenos Aires: Teseo. 
MERCOSUR. (1991). Tratado de Asunción para la constitución de un mercado común entre la República Argentina, la República Federativa del Brasil, la República del Paraguay y la República Oriental del Uruguay [Treaty of Asuncion for the constitution of a common market among Argentina, Brazil, Uruguay and Paraguay]. Asunción: MERCOSUR. Retrieved from https://www.mercosur.int/documento/ tratado-asuncion-constitucion-mercado-comun

MERCOSUR. (1994). Protocolo adicional al Tratado de Asunción sobre la estructura institucional del MERCOSUR: Protocolo de Ouro Preto [Additional protocol to the Treaty of Asuncion on the institutional structure of Mercosur: Protocol of Ouro Preto]. Ouro Preto: MERCOSUR. Retrieved from https://www. mercosur.int/documento/protocolo-ouro-pretoadicional-tratado-asuncion-estructura-institucionalmercosur

MERCOSUR. (1995a). MERCOSUR/CMC/DEC. No 5/95: Negociaciones con la Unión Europea [MERCOSUR/ CMC/DEC. № 5/95: Negotiations with the European Union] Montevideo: MERCOSUR. Retrieved from https://normas.mercosur.int/simfiles/normativas/ 25849_DEC_005-1995_ES_ConsolMCS.pdf

MERCOSUR. (1995b). MERCOSUR/GMC/RES. NNo 34/95: Grupo ad-hoc relacionamiento externo [MERCOSUR/ GMC/RES. № 34/95: Ad-hoc group external relations]. Montevideo: MERCOSUR. Retrieved from https://normas.mercosur.int/simfiles/normativas/ 25791_RES_034-1995_ES_Rel_Ext.pdf

MERCOSUR. (2000). MERCOSUR/CMC/DEC. NN 32/00: Relanzamiento del MERCOSUR. Relacionamiento externo [MERCOSUR/CMC/DEC. № 32/00: Relaunch of MERCOSUR. External relations]. Montevideo: MERCOSUR. Retrieved from https://normas. mercosur.int/simfiles/normativas/16558_DEC_0322000_ES_Relanzamiento_Relacion-

Externo_Acta\%201_00.pdf

MERCOSUR. (2001). MERCOSUR/XX CMC/DEC. № 08/01: Negociaciones con terceros países [MERCOSUR/XX CMC/DEC. № 08/01: Negotiations with third countries]. Montevideo: MERCOSUR. Retrieved from https://normas.mercosur.int/simfiles/normativas/ 10927_DEC_008-2001_ES_Negociaciones_ Terceros\%20Pa\%C3\%ADses_Acta\%201_01.pdf

Mercosur: Peligro de derrumbe [Mercosur: Danger of collapse]. (2005, May 29). La Nación. Retrieved from https://www.lanacion.com.ar/opinion/mercosurpeligro-de-derrumbe-nid708051

Meunier, S., \& Czesana, R. (2019). From back rooms to the street? A research agenda for explaining variation in the public salience of trade policy-making in Europe. Journal of European Public Policy, 26(12), 1847-1865.

Motta Veiga, P., \& Rios, S. P. (2007). O regionalismo pós-liberal na América do Sul: origens, iniciativas e dilemas [Post-liberal regionalism in South America: Origins, initiatives and dilemmas]. San- tiago: United Nations. Retrieved from https:// repositorio.cepal.org/bitstream/handle/11362/ 4428/S2007612_pt.pdf?sequence=1\&isAllowed =y

Motta Veiga, P., \& Rios, S. P. (2019). MERCOSUR experience in regional integration: What could Africa learn from it? Rabat: Policy Center for the New South. Retrieved from https://www.policycenter.ma/sites/ default/files/PCNS-PP1907.pdf

Nye, J. S. (1965). Patterns and catalysts in regional integration. International Organization, 19(4), 870-884.

Oelsner, A. (2013). The institutional identity of regional organizations, or Mercosur's identity crisis. International Studies Quarterly, 57(1), 115-127.

Olivera, F. (2009, May 27). La UIA se quejará de Venezuela en el Mercosur [UIA to complain about Venezuela in Mercosur]. La Nación. Retrieved from https://www.lanacion.com.ar/politica/la-uia-sequejara-de-venezuela-en-el-mercosur-nid1132664

Phillips, N. (2003). Hemispheric integration and subregionalism in the Americas. International Affairs, 79(2), 327-349.

Poletti, A., \& De Bièvre, D. (2020). Towards explaining varying degrees of politicization of EU trade agreement negotiations. Politics and Governance, 8(1), 243-253.

Rebossio, A. (2010, April 18). UE-Mercosur, novios otra vez [EU-Mercosur, engaged again]. El País. Retrieved from https://elpais.com/diario/2010/04/18/ negocio/1271595142_850215.html

Rebossio, A. (2011, December 10). Uruguay ve a Mercosur en su peor momento [Uruguay sees Mercosur at its worst]. El País. Retrieved from https:// elpais.com/internacional/2011/12/08/actualidad/ 1323344825_372207.html

Ribeiro Hoffmann, A. (2015). Politicization and legitimacy in MERCOSUR. In A. Hurrelmann \& S. Schneider (Eds.), The legitimacy of regional integration in Europe and the Americas (pp. 57-72). London: Palgrave Macmillan.

Rios, S., \& Doctor, M. (2004). Scenarios for untying the knots in market access. In A. Valladão \& P. Messerlin (Eds.), Concluding the EU-Mercosur agreement: Feasible Scenarios (pp. 103-124). Paris: Chaire Mercosur de Sciences Po.

Santander, S. (2005). The European partnership with Mercosur: A relationship based on strategic and neoliberal principles. Journal of European Integration, 27, 285-306.

Schelhase, M. (2010). The successes, failures and future of Mercosur. In G. Mace, A. F. Cooper, \& T. M. Shaw (Eds.), Inter-American cooperation at a crossroads (pp. 171-186). London: Palgrave Macmillan.

Schimmelfennig, F. (2018). European integration (theory) in times of crisis: A comparison of the Euro and Schengen crises. Journal of European Public Policy, 25(7), 969-989.

Sigal, E. (2010, October 11). El Mercosur, una herramienta para el desarrollo [Mercosur, a tool for 
development]. La Nación. Retrieved from https:// www.lanacion.com.ar/economia/el-mercosur-unaherramienta-para-el-desarrollo-nid1313749

Tallberg, J. (2010). The power of the chair: Formal leadership in international cooperation. International Studies Quarterly, 54(1), 241-265.

Torrent, R. (2003). Regional integration instruments and dimensions: An analytical framework. In R. Devlin \& A. Estevadeordal (Eds.), Bridges for development: Policies and instruments for trade and integration (pp. 119-134). Washington, DC: Inter-American Development Bank.

Tussie, D. (2003). Trade negotiations in Latin America: Problems and prospects. London: Palgrave Macmillan. von Bülow, M. (2010). Building transnational networks: Civil society and the politics of trade in the Americas. Cambridge: Cambridge University Press.

Yin, R. K. (2018). Case study research and applications: Design and methods. Los Angeles, CA: Sage.

Young, A. R. (2019). Two wrongs make a right? The politicization of trade policy and European trade strategy. Journal of European Public Policy, 26(12), 1883-1899.

Zelicovich, J. (2015). Juntos, pero no tanto: Un recorrido por la agenda de negociaciones comerciales del MERCOSUR (1991-2015) [Together, but not so much: A tour of the MERCOSUR trade negotiation agenda (1991-2015)]. Revista Integración y Cooperación Internacional, 21, 16-26.

\section{About the Author}

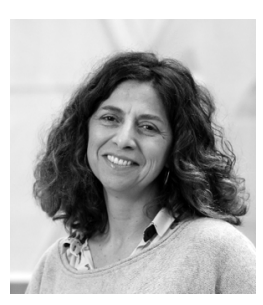

Andrea C. Bianculli is Assistant Professor at the Institut Barcelona d'Estudis Internacionals (IBEI). Her research, which lies at the intersection of comparative and international political economy, examines the relationship between trade, regulation, and development, with a regional focus on Latin America. Her research has been published in Administration \& Society, Canadian Journal of Latin American and Caribbean Studies, Global Social Policy, Journal of European Social Policy, and Regulation \& Governance. She is the Author of Negotiating Trade Liberalization in Argentina and Chile: When Policy Creates Politics (2017, Routledge). 